\title{
THE VILLAGE ACCOUNTING KNOWLEDGE AND COMPREHENSION ENHANCEMENT FOR VOCATIONAL HIGH SCHOOL ACCOUNTING TEACHERS IN TULUNGAGUNG
}

\author{
Cipto Wardoyo ${ }^{1}$, Rizky Firmansyah ${ }^{2}$, Slamet Fauzan ${ }^{3}$, Adam Gumilang \\ Rahmawan $^{4}$ \\ 1,2,3,4,5Accounting Department, Universitas Negeri Malang, Malang, Indonesia \\ 1 cipto.wardoyo.fe@um.ac.id, ${ }^{2}$ rizky.firmansyah.fe@um.ac.id, ${ }^{3}$ slamet.fauzan.fe@um.ac.id, \\ 4adam.gumilang.1904226@students.um.ac.id
}

\begin{abstract}
Considering the various regulations that issued by government such as Act Number 2014 in relation to Villages which contained the Village Government Authorities, Rights, and Obligations as well as The Minister of Home Affairs Regulation (Permendagri) Number 113 Year 2014 concerning Village financial management which included the Guidelines and Stages to avoid Village financial management mistakes and misunderstanding between Village government in its organization. Educational institutions have executed the Village Accounting subjects that will be studied by Vocational High School students in 2018. Thus, it required knowledge and understanding about Village Accounting for Vocational High School Accounting teachers, especially in Tulungagung. In this practice, the researcher presented understanding through lecture and practicum methods using SISKEUDES application in order to generate competent accounting teachers.
\end{abstract}

Keywords: village accounting, SISKEUDES, vocational high school accounting teacher

\section{A. Introduction}

This community service was based on the allegation of the enactment of Village law Number 6 year 2014 which initiates the authority to control income and funds for village welfare by Village Government. The Village Fund is aspired for village development which aims to develop the rural welfare and improve the village economy quality in order to dissolve the poverty. Consequently, the government issued various regulations such as Act
Number 2014 in relation to Villages which contains the Authorities, Rights and Obligations of Village Governments as well as Permendagri Number 113 year 2014 concerning Village Financial Management which included the Guidelines and Stages of Village financial management in order to avoid the mistake and misunderstandings from the Village Government in its organization.

Village Fund Allocation is a fund owed by the Regency/City 
Government for the village which is obtained from the central and regional financial balance funds accepted by the Regency/City. Village Revenue and Expenditure Budget, henceforth abbreviated as APB Desa is an annual event that the village government's financial idea is being discussed and mutually agreed by the Village Government and BPD, which is resolved by a Village Regulation.

The funds which is provided for village welfare is closely associate to reasonable distribution of village development. It is planned to be a focus from APBN (State Revenue and Expenditure Budget) which amount to billion rupiahs. Thus, It needs an ample administration with competent human resources to manage. As return, the government presents an application called SISKEUDES (Village Finance System) to alleviate the village government in organizing the village finance. Subsequently, Republic Indonesia deputy minister of finance,Prof Mardiasmo inquired Educational Institution to prepare graduates who comprehend in government accounting to fulfil the necessity of competent human resource. Therefore, the government assigned the minister of education to put the content of village government accounting lessons in Vocational High School subject since 2017. By means of this policy, teachers are required to master the competence of village government financial systems but in reality, Indonesia State universities create graduate teacher candidates such as Malang State University, Surabaya State University, Yogyakarta State University etc. The Vocational High School curriculum not restrains Village Financial System course. Hence, it can be observed that there is an inequality between the competencies possessed by teachers and the competencies needed in schools. Yaya Mulyana Aziz, A. (2021).

For these reasons, this community service was expected to enhance the Vocational High School accounting teacher's knowledge to comprehend the Village financial system which includes planning, budgeting, administration, and reporting. The village government performs the planning activity in order to develop the village as its authority. Implementation is the stage of 
accomplish the existing plan and will be completed in stages. Budgeting is the process to input the data of activities in a year. Administration is the stage of recording data in the cash book, bank book, and tax subsidiary ledger. Reporting is the stage of organizing a budget and the realization of Village Revenue and Expenditure Budget. Following this service activity, it is anticipated that teachers will have an ample knowledge about the village financial system so that they can deliver their knowledge simply and practically. Subsequently, when the teachers comprehend the material of village government accounting, it is assumed that students can cleanly understand the material that is given by their teachers. Hence, educational institutions can produce graduates who are competent and willing to take on an important role as a village financial managers. Based on the analysis above, the focus problems that dealt with partners could be classified as follows:

1. The lack understanding of village financial system (SISKEUDES) application by Vocational High School accounting teachers in Tulungagung
2. The lack skill to operate village financial system (SISKEUDES) application by Vocational High School accounting teachers in Tulungagung

To surmount the lack understanding of governmental accounting subjects, our team was intended to explain and practice the Village Accounting through participation of planning, budgeting, administration and reporting the village finance. The practice included manual practice and simulation of SISKEUDES application to afford a guide book which it could make easier to comprehend village financial accounting systems. Deni S, T. B. (2019).

\section{B. Method of Implementation}

This community service employed training and mentoring methods. In the training activity, the concept of village financial system would be delivered into a lecture method. It was aimed to provide understanding before the participants practiced using provided software.

The village accounting system (Siskeudes) is a simple application 
developed by the Financial and Development Supervisory Agency (BPKP) with the Directorate General of Village Government Development, Ministry of Home Affairs. This application was developed in order to advance the quality of village financial governance. The features in the application are made simple so that it is easy to operate. This application is also equipped with an Internal Control System. With the once-process input of existing transactions, it can construct an administrative documents and reports which is suitable with legislation. Pajak, J. A. (2020)..

Furthermore, the teacher was escorted to install the software on their laptops and practice. The mentoring method was proposed to provide motivation and attached supervision during the activity. With this assistance, teachers were required to comprehend completely about the village financial system application so the material could be taught to their students.

Afterward, participants practiced to input the Village RPJM and RKP data manually. In this practice, they would execute two stages. In the first stage, they would utilize Village Accounting with the researcher guidance so that participants can apply Village Accounting efficiently. RI, K. K. (2018).

In the second stage, participants would be assigned a worksheet to elucidade problems related to Village Accounting from the given material. After completing the worksheet, there was an evaluation process about the given problem.

For preparation, the researchers took the following steps:

1. Discover the expected competencies from the government accounting subject at the Vocational High School level through discussion

2. Accumulate relevant references specifically the village financial system references

3. Designing the books needed for village financial administration

4. Designing a selection of relevant transactions

5. Designing the village financial report format

6. Perform community service activities in schools to elucidate and practice the village financial 
administration as well as compose village financial reports which include APBD and Village wealth reports

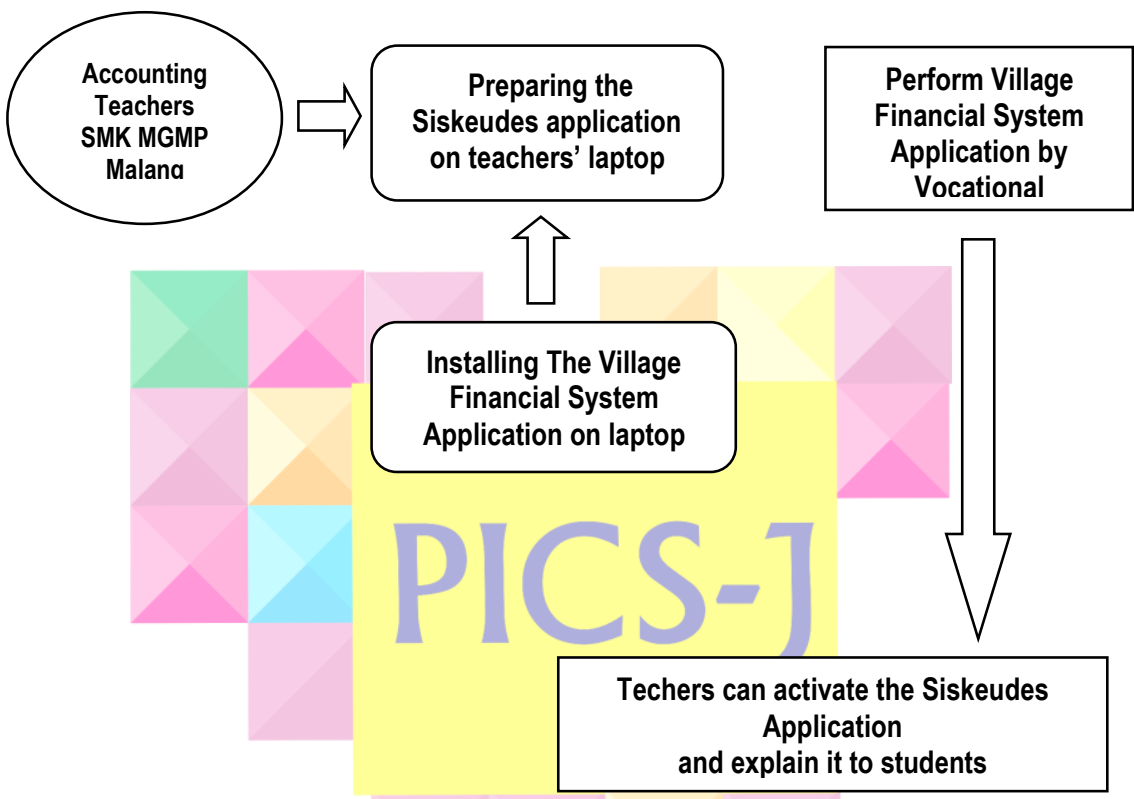

Figure 1. Design of PKM MGMP for Accounting Teachers at Vocational High

\section{School in Tulungagung}

\section{Result and Discussion}

On the first day of training, the general concept about village financial accounting by Siskeudes application was given through a lecture method. The Siskeudes application was developed to facilitate the quality improvement of village financial governance with the village financial management process. The processes comprise Planning and Budgeting. It included the alignment of the MediumTerm Development Plan Village (RPJMdes) which contains the vision and mission of the village head, direction of village development policies as well as the strategies which covers the village administration, implementation of village development, village community development and village community empowerment; The Village Government Work Plan (RKPDes) is an amplification of the RPJMdes for a one year period. Then, Village Revenue and Expenditure Budget (APBdes) which is the village government's annual financial plan is 
conversed and agreed by the village government and the Village Consultative Body (BPD). Thus, it will be instructed in the Village Regulation. Second, implementation and administration which consist of administration of revenues and expenses, administration of books, and tax obligations. Third, Reporting and Accountability involve reports on the realization of the village budget per budget source, implementation of the first and final semester APBD, and the APBD budget in a year.

As the spearhead of the country's economy, MSMEs are able to contribute greatly to the country. MSMEs are able to absorb a lot of the workforce and encourage increased productivity which in turn can boost the

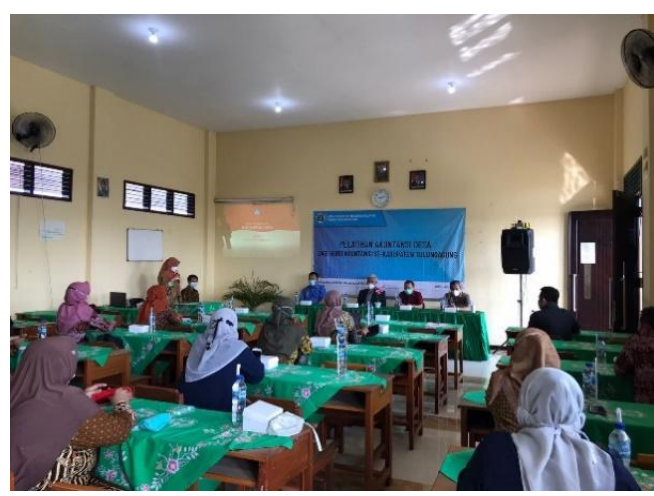

Figure 2. Picture of the lecture activity in delivering Village Accounting materials
The finance management between village and the central, province, district or city government is not discrete. By means of the limited number and capacity of village officers, the village financial management should be remained simple without conceding the transparency and accountability principles. In the sphere of organizing the village finance, it is essential to identify the risk of administrative and substantive errors which can cause legal problems by insufficient competence of a village head and officer in the practice of village financial administration, reporting and accountability. Then, the achievement of village development is the result of a well-managed village financial management.

Consequently, participants were introduced for the Village Accounting implementation by inputting Village RPJM and RKP data during the Practice activity. The data consists of the village's Vision, Mission, Goals and Targets according to the Village RPJM that has been organized. Before inputting the Village RPJM and RKP, the participants had to input general village data first. Thus, 
budgeting activities requires to input activities data in a occupied year.

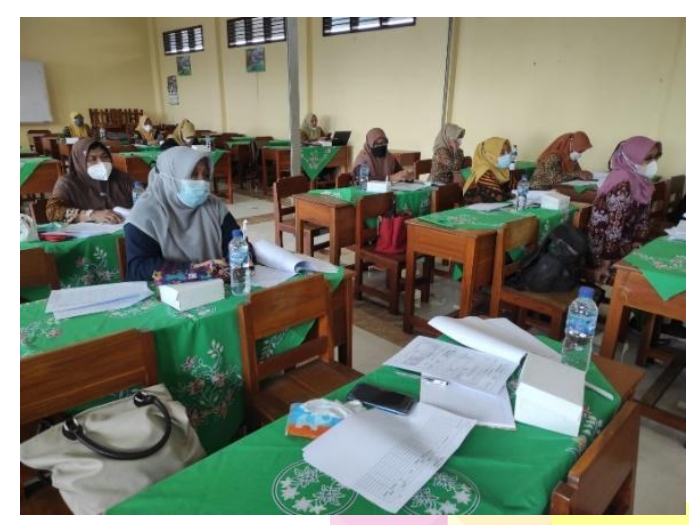

Figure 3. Picture of practical study

In the administration stage, there were two activities as follows:

1. Administration of village revenue is the process of recording Village Original Income, Transfer, and other Income by Village treasurer

2. Expenditure administration is accustomed to administer village expenditure which it begins with a Payment Request Letter (SPP) proposal from the Village Finance Implementing Officer (PPKD).

The proposed administrative practice involved the practice of designing and fulfilling data based on transactional evidence into the following books:

1. General Cash Book and Subsidiary Cash Book

2. Tax Book

\section{Bank Book}

Furthermore, the explanation and organizing report implied the following stages:

1. Construct a proposal based on the vision and mission as delineate in the budget preparation

2. The budget is compiled from income, expenditure, and finance accounts

3. Perform the budget. It is recorded from budget realization. The realization must be recorded in the general cash book, subsidiary cash book, bank book, tax book, inventory book (as mentioned in the financial administration stages above) where the realization must be maintained by transactional evidence.

4. The Village financial accountability reports are generated which consist of:

a. Arrange an accountability report of the APBD realization for a certain budget year

b. The Village wealth report for a certain fiscal year

5. A central and local government programs report. 


\section{Conclusion}

Village Accounting Training was performed successfully. Participants were very enthusiast to take part in every activity that was created cooperatively and conducively. As a result, participants could operate the Siskeudes application and they could applied Village accounting easily as well as enhance their comprehension and skills toward Village accounting. Participants were fully understand about the Siskeudes application and its functions as well as how to appropriately instigate this application for the future needs.

This training activity was performed smoothly and promptly because the participants were very supportive during lecture and practice activity so that they could build up the conceptual understanding. For this reason, the next activity could be designed on a larger scale since the Tulungagung Vocational teachers were able to facilitate the activity efficiently in order to impart the understanding of Village accounting.

\section{REFERENCES}

Yaya Mulyana Aziz, A. (2021). The
Role Of Village Equipment In The Accountability Of Cinta Mulya

Village Government Sumedang

District West Java Province.

Pasundan International Of Community Services Journal (PICS-J), 42-43.

Pajak, J. A. (2020). Analisis Penggunaan Siskeudes dalam Pengelolaan Dana Desa. Diambil kembali dari Jurnal Akuntansi dan Pajak: https://jurnal.stieaas.ac.id/index.php/jap/article/vie w/770/pdf

RI, K. K. (2018). Aplikasi Siskeudes untuk Transparansi Keuangan Desa. Diambil kembali dari https://kominfo.go.id:https://komi nfo.go.id/content/detail/15734/apl $\underline{\text { ikasi-siskeudes-untuk }}$ transparansi-keuangandesa/0/artikel_gpr

Peraturan Meteri Keuangan nomor 93 tahun 2015 tentang Tata Cara Pengalokasian, Penyaluran, Penggunaan, Pemantauan dan Evaluasi Dana Desa

Undang-Undang Nomor 2014 tentang Desa yang memuat Kewenangan, Hak dan Kewajiban Pemerintah Desa serta Permendagri Nomor 
113 Tahun 2014 tentang

Pengelolaan Keuangan Desa

Deni S, T. B. (2019). Implementation

Of Village Business Management

Board (Bumdes) Village Of

Cibalanarik, Tanjungjaya District

Tasikmalaya Region. Pasundan

International Of Community

Services Journal (Pics-J), 2.

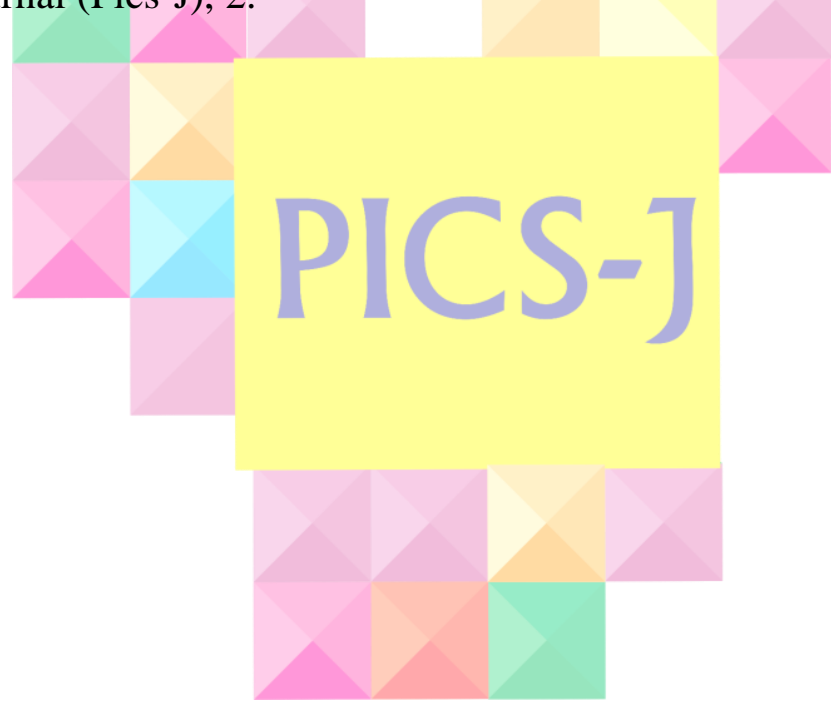

